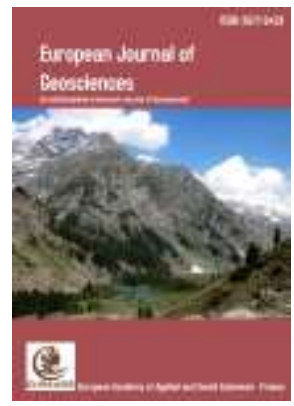

Research Article

\title{
Damage Assessment and Spatio-Temporal Mapping Using Object Based Image Analysis Technique on Floods-2015 in Southern Punjab, Pakistan
}

\author{
Malik Abid Hussain Khokhar ${ }^{\mathrm{a}}$, Sadaf Javed ${ }^{\mathrm{b}}$, Hisham Bin Hafeez Awan ${ }^{\mathrm{a}}$, \\ Ishtiaq Yousaf ${ }^{\mathrm{a}}$, Amir lqbal ${ }^{\mathrm{C}}$, Liaqat Ali Waseem ${ }^{\mathrm{d}}$ \\ ${ }^{a}$ NUST Institute of Peace and Conflict Studies (NIPCONS), National University of Sciences \& Technology (NUST), 44000 Islamabad, \\ Pakistan. \\ ${ }^{b}$ Dept of Meteorology, COMSATS University (44000), Islamabad, Pakistan. \\ ${ }^{c}$ Department of Space Science, Institute of Space Technology (44000), Islamabad, Pakistan. \\ ${ }^{d}$ Department of Geography, Government College University (38000) Faisalabad, Pakistan.
}

Received: 03 November 2020 / Revised: 17 December 2020 / Accepted: 12 January 2021

\begin{abstract}
Floods are the natural disasters which not only harm human lives but also damage entire structure in the inundated area. Pakistan has been witnessing extensive floods since very long because of long and severe spells of monsoon rainfalls with abrupt diurnal and seasonal disparity in the temperature level every year. Floods of 2010 and 2014 were so severe that they had broken the disaster record of earthquake-2005 in Pakistan and floods of 2015 had devastated the southern Punjab badly. These floods have damaged socioeconomic activities and people were displaced from the flood prone areas. Southern Punjab has been facing this calamity frequently from 2010 onward which resulting to huge destruction and gigantic loss of human lives every year. An immaculate large area of the Southern Punjab was damaged with crop land, built-up areas and road networks. To assess the damages and spatiotemporal mapping during flood period, remote sensing and GIS techniques have been incorporated by using spatial statistical and object-based image classification techniques. These techniques have been applied for estimating damages, mapping and extracting flood extents by embedding NDVI, NDBI and NDWI methods into object-based image analysis. This paper concludes assessment of damages, various extents of flood and accuracy assessment $\left(79.3 \%\right.$ and $\mathrm{K}_{\text {hat }} \mathrm{0.72}$ ). Outcomes of the paper would be very beneficial for disaster management authorities for mitigating future floods and helpful for flood monitoring departments to guide competent management authorities at all tiers for quick response and rehabilitation programmes.
\end{abstract}

Keywords: Floods, damage assessment, Disaster Management, Punjab.

\footnotetext{
* Corresponding author: Email: abid.geo@nipcons.nust.edu.pk (M.A.H. Khokhar).

Available online: 25 January 2021

DOI: https://doi.org/10.34154/2021-EJGS-0013/euraass

Journal reference: Eur. J. Geosc. 2021, 03(01), $09-18$

ISSN-E: 2677-643X.

(C) European Academy of Applied and Social Sciences. Euraass - 2021. All rights reserved.
}

Cite as: Khokhar, M. A. H., Javed, S., Awan, H. B. H., Yousaf, I., Iqbal. A. and Waseem, L. A. (2021). Damage Assessment and Spatio-Temporal Mapping Using Object Based Image Analysis Technique on Floods-2015 in Southern Punjab, Pakistan. Eur. J. Geosc. 03(01), $09-18$. 


\section{Introduction}

Floods are taking place all through the world with severe devastating impacts on local and global levels with various intensity, frequency and influence (Shakeel et al., 2015). Sequel to damages, types of natural disasters are categorized as earthquakes, land sliding, hurricanes, droughts and floods which affect the land and infrastructure widely (Ahmed et al., 2014). Devastation of floods is estimated by physiographic and human losses (Guo et al., 2014; Sowmya et al., 2015). Important factors of flood hazard are rapid heavy rainfall, speedy and an immense volume of water flow in the rivers along with their tributaries (Bhuiyan and Baky, 2014; Kalantari et al., 2014). Floods have become a frequent phenomenon in Pakistan (Memon, 2015). The intensified damages caused by the floods because of local and global climate during the last thirty years (lqbal et al., 2015). In the flood reports of 2015, it is shown that intensity of extreme rainfalls have increased many folds at the global scale in terms of magnitude and frequency (Shakeel et al., 2015). By virtue of its geographical location and poor land use planning for combating effects of pre, during and post rainfall, Pakistan is one of the most affected countries with the evidence from history starting from 1973 (Shah, 2020). If we take floods only, the yearly cycle of floods in Pakistan goes from years 1955, 1973, 1976, 1980, 1988, 1992, 2010, 2011, 2012, 2014 and 2015 (FFD and Miinistry of Water \& Power Pakistan, 2015).

Since 1973, floods in Pakistan have affected about 41 million people as a whole (Shakoor, 2015). According to the flood damage results of 2015 report, an amount of Rs. 85 billion and Rs. 100 billion was estimated as cost of damaged crops and household infrastructure respectively. In addition to aforementioned losses, huge costs were incurred for reconstruction and rehabilitation in all the sectors including health, communication, transportation, energy, agriculture, irrigation and sanitation facilities (FFD and Miinistry of Water \& Power Pakistan, 2015). Pakistan has been experiencing 'super floods' (as termed by the Government of Pakistan) since 2010 (Kirsch et al., 2012). On $7^{\text {th }}$ Jul 2015, heavy monsoon rainfall occurred in the northern and north-eastern regions of Pakistan thus basins of the River Indus, Jhelum, and Chenab filled with a gigantic run off which resulted to flash floods in Chitral, KP, Sindh and Punjab provinces (FFD and Miinistry of Water \& Power Pakistan, 2015). Heavy monsoon rainfall, fast snow melting in the northern areas of the country and outpouring from glaciated lakes from $1^{\text {st }} \mathrm{Jul} 2015$ brought about flash floods and inundation in the River Indus at a numerous places across Pakistan (NDMA Report Pakistan, 2015).

On $22^{\text {nd }}$ Jul 2015, a combination of the devastating flash flood in The River Indus because of multiple reasons including speedy snow melting, monsoon downpours and GLOFs (Glacial Lake Outburst Flow) thus villages across the banks of the river Indus were deluged (PMD, and Flood Forcasting Division, 2015). The Suleman range received thunderstorms with heavy rainfall and resulted into flash floods down the hills towards Rajan Pur, Multan and Dera Ghazi Khan Districts (CWSA Peace Resiliance, 2015). As per unequivocal information of NDMA (National Disaster Management Authority) and PMD (Pakistan Meteorological Department), 2750 villages / mouzas located in District Layyah, Rahim Yar Khan, Dera Ghazi Khan, Muzaffargarh, Multan and Rajan Pur were directly affected by floods of 2015 (PMD, and Flood Forcasting Division, 2015; Isa, 2015). As Spill ways of Tarbela Dam were opened, most of the levees in Dera Ghazi Khan were collapsed. As per noted figures of the river Indus, the water passed from Kot Mithan in the District of Rajan Pur was approximately 8000,000 cusecs on daily basis $\left(27^{\text {th }}\right.$ Jul to $7^{\text {th }}$ Aug 2015) (NDMA Report Pakistan, 2015).

That massive water flow not only destroyed the villages and towns of District Rahim Yar Khan and Muzaffargarh but also District Multan, Dera Ghazi Khan and Layyah received their equal share in the destruction. Along with the household annihilation most of the $256 \mathrm{Km}$ area along the river bed having agricultural land spread across thousands of acres were also tumbledown (PMD and Flood Forcasting Division, 2015). Overall 1.933 million people and 4,634 villages have been affected in the Punjab which includes $33.44 \%$ women, 33.86\% males and 32.08\% were children during floods of 2012 to 2015 (FFD and Miinistry of Water \& Power Pakistan, 2015). It was estimated that 1 million acres of agricultural land including fodder and staple crops were affected severely. Almost 0.3 million farmers and 10,716 households were damaged (FFD and Miinistry of Water \& Power Pakistan, 2015) which brought about destruction of several economic activities, unemployment and health crises (NDMA Report Pakistan, 2015).

Application of appropriate land use planning in the flood prone areas and accurate knowledge of spatial flood extents are the helping tools for the reduction of flood effects/ damages and overcoming of emergencies for the relief efforts as well as rehabilitation programmes (Hazarika et al., 2015). With the advent of technologies like Geographic Information System (GIS) and Remote Sensing (RS), advancements have been made in disaster risk reduction and damage assessments. GIS is an information system which can process, analyse, and visualize spatial data including remotely sensed imageries. RS involves the acquisition of images of earth surface for improved observation of naturally occurring phenomenon including floods ( Ahuchaogu et al., 2015). 
Usually, floods in Pakistan affect large areas. Therefore, traditional and manual methods (aerial photography) for assessing damages consume a lot of resources like time, efforts and manpower. Besides the availability of fresh and up-to-date information of ongoing floods, aerial over views are difficult and sometimes weather determinism also doesn't permit to get the required results. In this regard, satellite data plays an important role for damage assessment with visual and statistical interpretations which is not only gives prompt flood extents but also helps in land use planning, topographical details and climatic conditions (Memon et al., 2015).

In this research paper, USGS resources were used for acquisitions of Landsat 8 (OLI), Sentinal-1, Google Imagery and MODIS data for floods mapping as these are freely available with reasonable resolutions. Object Oriented Classification method was adopted for flood extent mapping. Moreover, MNDWI, NDVI and NDBI were used for damage assessments. The main purpose of this research was to carry out spatio-temporal mapping, flood extents, damage assessments in the Southern Punjab to help concerned authorities in decision making and mitigating floods to minimize damages of such future floods.

\section{Materials and Methods}

\subsection{Study Area}

In figure 1 , Study area is bounded within the extent of $27.67^{\circ} \mathrm{N}$ to $31.36^{\circ} \mathrm{N}$ Latitudes and $69.26^{\circ} \mathrm{E}$ to $71.95^{\circ} \mathrm{E}$ Longitudes with total area $3193.04 \mathrm{Sq}$. Km. Its elevation ranges from 81 meters to 158 meters above sea level. Major rivers of the Punjab province pass through this area which inundate almost every year that have brought about a lot of sever damages of human, livestock agriculture and built-up infrastructure.

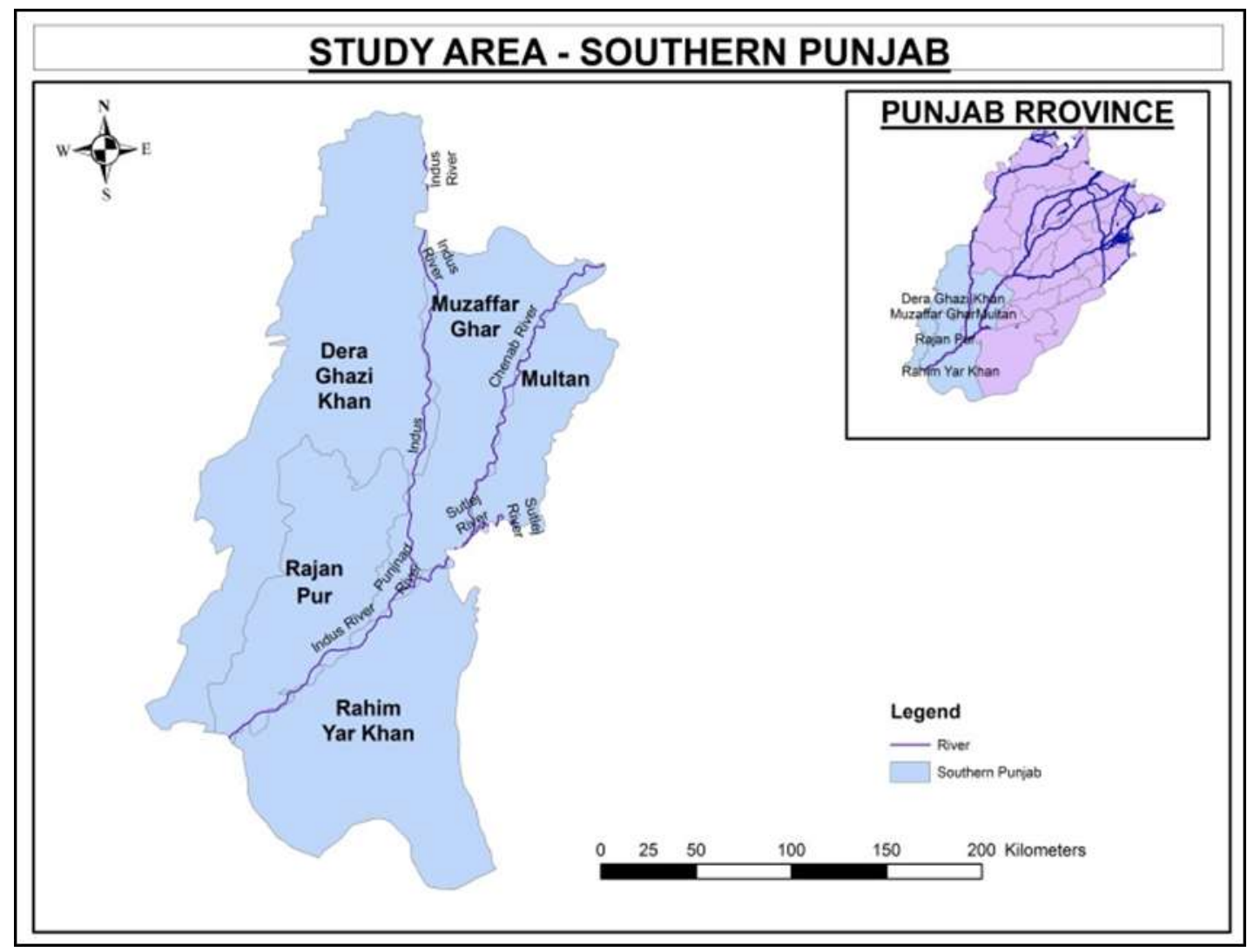

Figure 1. Study Area - Southern Punjab. 


\subsection{Remotely Sensed Data}

Four images of MODIS taking Aqua/Terra Satellite Sensor on board were used for inundation extraction in the study area and the said inundated flood extant had been verified by the Landsat-8 (OLI) as cross validation evaluation of MODIS. MODIS imagery was downloaded (one image that covered the whole study area) through the website (https://lance.modis.eosdis.nasa.gov) and the said imagery was comprised on 7-2-1 bands, right from the beginning of flood season to the end of floods season. One image was taken from pre-flooded period ( $\left.1^{\text {st }} \mathrm{Jul} 2015\right)$ and one image was taken after the floods ( $16^{\text {th }}$ Aug 2015). However, other images were taken during flooded season on daily basis with temporal resolution of 0.5 meter and spatial resolution of 250 meter. Though, intrusion of clouds was $10 \%$ but overall quality of the image was good to perform analysis.

Table 1: Data Acquisition

\begin{tabular}{lcccc}
\hline Satellite & Band & Row/ Path & Resolution & Cloud Cover \\
\hline Landsat 8 (OLI) & $4-8$ & $39 / 151$ & 30 Meters & $10 \%$ \\
MODIS & $2-6$ & $\&$ & 250 Meter & $0 \%$ \\
Sentinel-1 & C-SAR & $39 / 152$ & 10 Meters & $0 \%$ \\
\hline
\end{tabular}

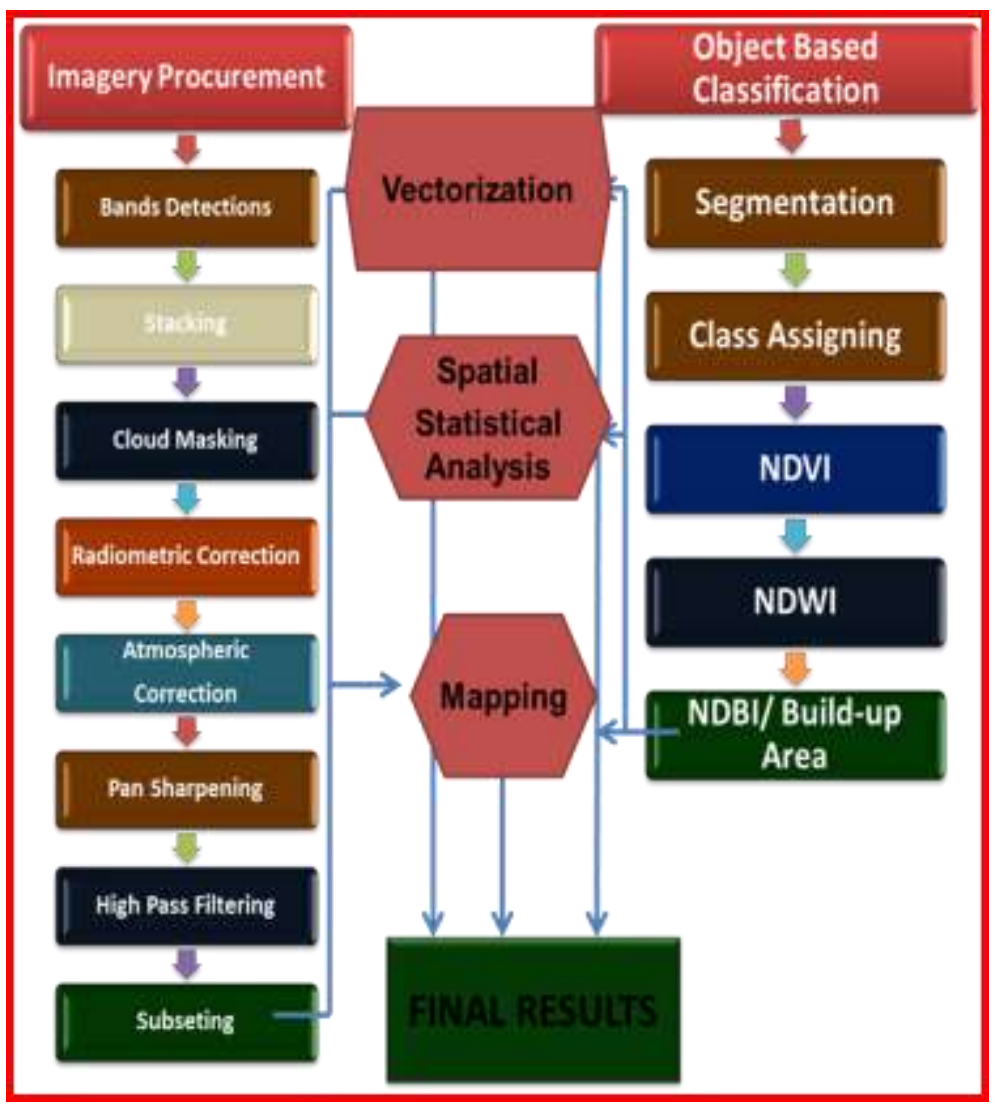

Figure 2. Flow Chart of Methodology. 


\subsection{Pre-Flood Extents}

Pre-Monsoon extents of the rivers and other water bodies / tributaries were derived at 30-meter resolution from Landsat imagery (table 1) in the study area. The maps were generated after executing data using MNDWI (Modified Normalized Difference Water Index) calculations. Material and data were used from Landsat-8. OLI imagery taken during $1^{\text {st }}$ Jun 2015 to $30^{\text {th }}$ Jun 2015 and analysis were based on pixel quality and object-based image classification in e-cognition then exported the derived extents in vector format and finally overlaid on Google Imagery in Disaster Watch software. Disaster watch is software which gives run time analysis and it can be embedded with web-based GIS as well.

\subsubsection{MNDWI (Modified Normalized Difference Water Index)}

Deriving inundating extents in the study areas, the mapped area was validated using Landsat-8. MNDWI was formulated by Landsat-8 (OLI) Satellite using of SWIR bands and Visible (Green) Bands with the following equation/ formula.

$$
M N D W I=\frac{\text { Green }- \text { SWIR }}{\text { Green }+ \text { SWIR }}
$$

MNDWI index was calculated by water reflectance (maximized) using green wavelength, SWIR low reflectance (minimized) of water bodies and high SWIR reflectance using soil \& vegetation features where values of vegetation \& soil were in between -1 to 0 and water values were in positive integers. Negative values were enhanced and positive values were suppressed.

$$
L W M=\frac{I R}{\text { Green }} \times 100
$$

Normally, a standard range of land \& water mask varies from 0-255. However, value of water was ranging from 0 to 57 having shallow waters, also which range from 28 to 37 in e-cognition as formulated in equation 2 . The two above quoted equations were proved ineffably suitable for inundation of flood mapping

\subsubsection{NDVI (Normalized Difference Vegetation Index)}

NDVI is calculated by the equation 3 which is narrated below (Memon et al., 2015 ; Tamta and Bhadauria, 2015). In NIR Band vegetation reflects higher than that of visible band. As per equation mentioned below, red band was subtracted from NIR and divided by sum of NIR and Red band which represents the ratio from -1 to 1 and over 6 depicted the dense green vegetation.

$$
N D V I=\frac{N I R-\operatorname{Re} d}{N I R+\operatorname{Re} d}
$$

\subsubsection{NDBI (Normalized Built-up Index)}

NDBI is different from NDVI. Because NDBI deals with extraction of built-up areas from the satellite images whereas NDVI only deals with the vegetation extraction as mentioned above in serial 2.5. So, damages of built-up area were extracted from NDBI and BU (Built-up) equations as mentioned below. These were extracted from Landsat $8 \mathrm{OLI}$ where values of TM Band 5 is subtracted from TM Band 4 using object based classification in e-cognition (Belal, 2011 ; Tamta and Bhadauria, 2015). Layer was vectorized in shape file. This was further overlaid on the image. Landsat 8, its Bands TM5 and TM4 carry wavelengths 1.67 and 0.83 respectively. Urban areas from Landsat 8 (OLI) images were derived using equation 4 and equation 5. However, MODIS data had the same central wavelength (1.67 \& 0.83) for Band 6 and Band 2. Resultantly, $\mathrm{NDBI}_{\text {MODIs }}$ was derived from the said MODIS bands using equ. 6 which is stated below (Zhang et al., 2014).

$$
\begin{aligned}
& N D B I=\frac{\text { Band } 5-\text { Band } 4}{\text { Band } 5+\text { Band } 4} \\
& B U=N D B I-N D V I \\
& N D B I_{M O D I S}=\frac{\text { Band } 6-\text { Band } 2}{\text { Band } 6+\text { Band } 2}
\end{aligned}
$$

\subsection{Object Based Image Classification}

Object based image classification was used to prepare water extent and the same was separated from the different image then added into final output. In this classification, multiscale segmentation algorithm was used. Parameters values of segmentations were ' 1 ' 
for all the layers as layer weight, scale was 20 , shape and compactness were 0.5 each. Classifier algorithm was near neighbour. For which auto hyperparameters were utilized to run classification.

\section{Results and Discussion}

This section of the paper constitutes the results of the methods used from equ. 1 to 6 and spatio-temporal mapping and damages are discussed in the successive paragraphs with figures and table 2. Output of MNDWI was in the form of inundated water extents which were calculated to display as pre-flood and post-flood extents. NIR and SWIR bands gave low reflectance during detection of water in segmentation of object-based classification. In segmentation, shape size was opted 0.2 , compactness was 0.8 and scale parameters were 25 . Flood extents were derived on the daily basis and the development of the floods were increased gradually.

Approaches of MODIS and Landsat 8 became helpful in deriving the flood extents temporally. Root Mean Square Error (RMSE) of MODIS and Landsat images were below 0.5. Mapping of the said inundation was generated from the beginning of flood as well as in its full spring in the river course from $1^{\text {st }}$ Jul 2005 to $16^{\text {th }}$ Aug 2015. Extracted inundated areas from the aforementioned satellites were noted down in Table 2, where it has been shown that Rajan Pur District was inundated highly with 1028 sq. Km and Multan District remained at the lowest in inundation. Maximum agricultural land damages came greatly with 286554 sq acres in DG Khan District. From NDVI, damages of vegetation were extracted from object-based classification techniques.

\subsection{Spatio-Temporal Mapping of Growing Flood}

Spatio-temporal mapping is a key parameter to distinguish flood course and its damages over the flood risk prone areas in terms of damages. Floods of 2015 occurred from $9^{\text {th }}$ Jul 2015 and prevailed up to $20^{\text {th }}$ Aug 2015. In this regard, figure 3 to figure 7 are shown to highlight this flood in the study area. Figure 3-4 are the showing the water courses (flow course) before the occurrence of floods. Major part of the River Indus falls in the DG Khan, Rajan Pur and Rahim Yar Khan districts so major anticipated floods occurred in the abovementioned districts. Keeping spatial and visual interpretations of the fig. 3 and the fig. 4 , it is clearly evident that pre-flood paths of the rivers were between the levees and no terraces deemed elongated even near the meanders of the rivers.

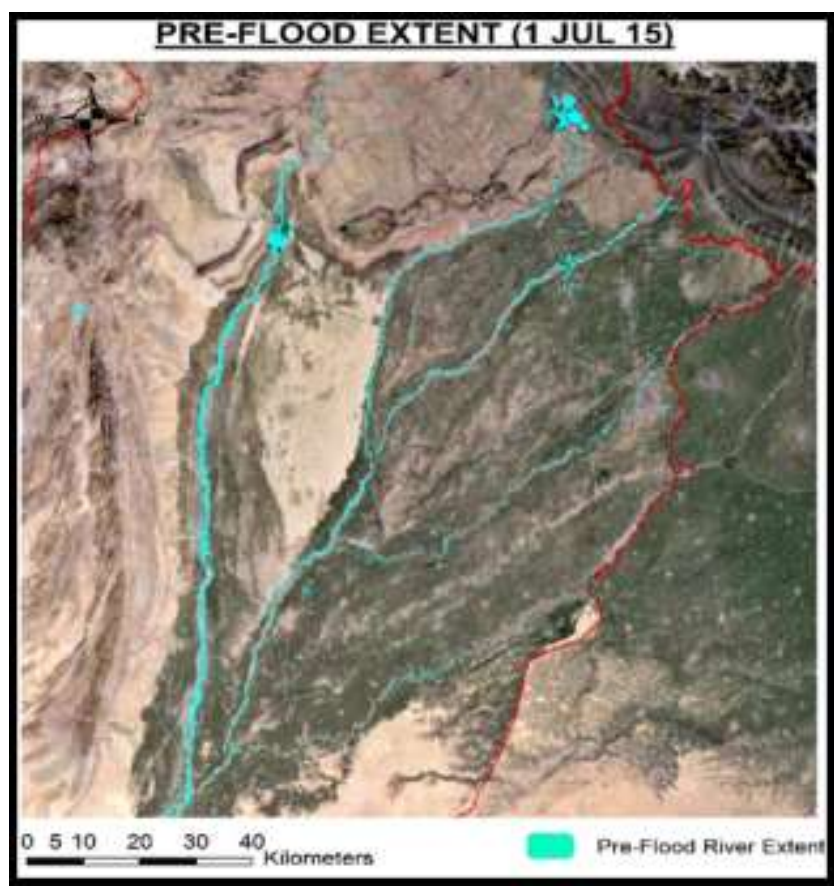

Figure 3: Pre-Flooded Extent ( $1^{\text {st }}$ Jul 2015).

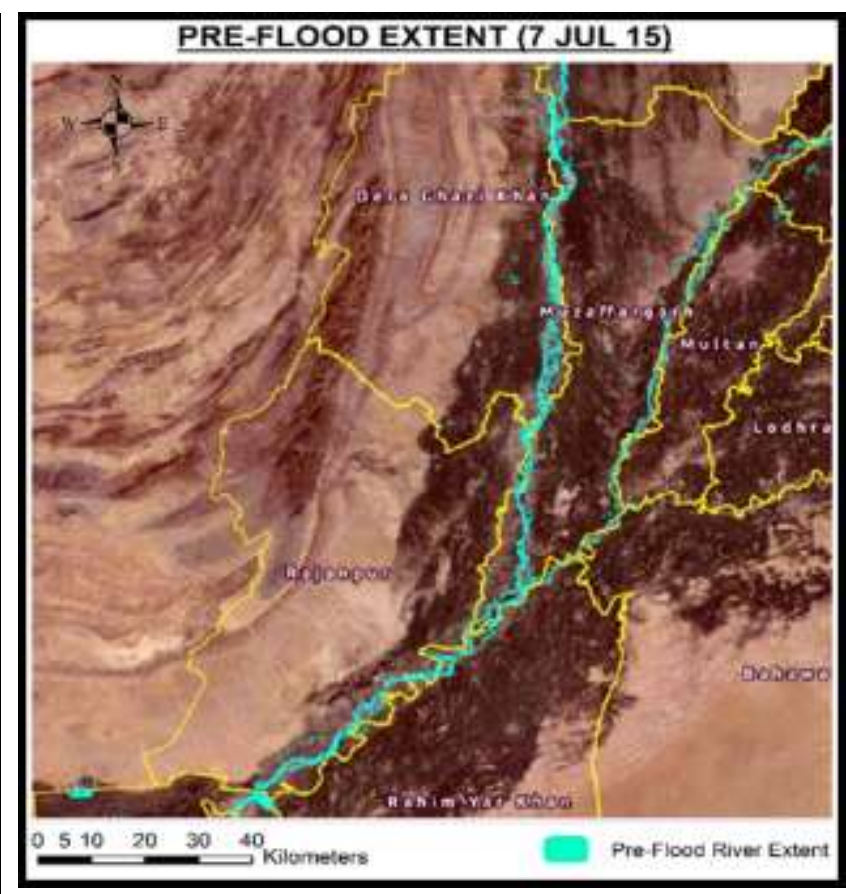

Figure 4: Pre-Flooded Extent $\left(7^{\text {th }}\right.$ Jul 2015). 


\subsection{Damage Assessment}

All the districts under study area were damaged severely. The damages shown in table 2 were derived from the district statistical report of flood and from NMDA report on flood 2015 (NDMA Report Pakistan, 2015). Damages of inundated area, built-up area and agricultural land have been calculated by object-based classification using equation 1 to 6 and details are summed-up in numerical form as mentioned the same in the table 2. The said table is showing that Rahim Yar Khan and DG Khan districts are submerged severally in this flood along with damages to crop lands. Most of the length of road network was widely damaged along with displacement of people which surpass all the above-mentioned losses.

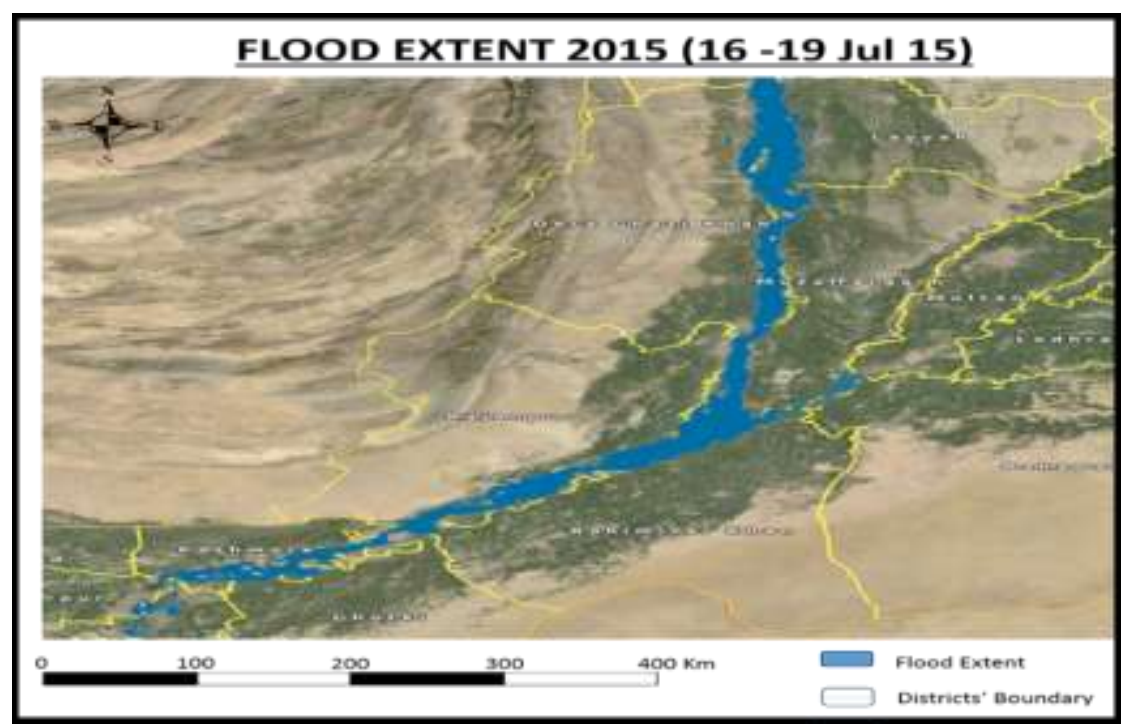

Figure 5: Flood Extent 2015 (16th -19th Jul 2015).

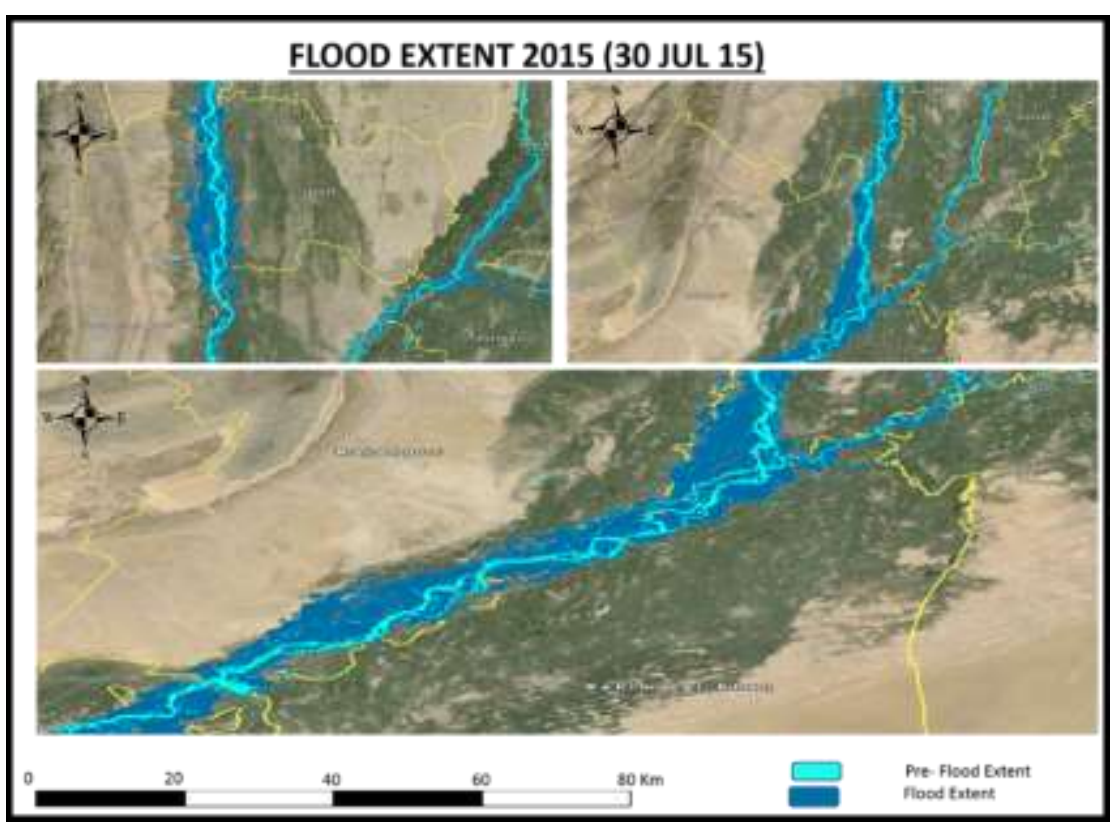

Figure 6: Flood extent 2015 (30th Jul 2015). 


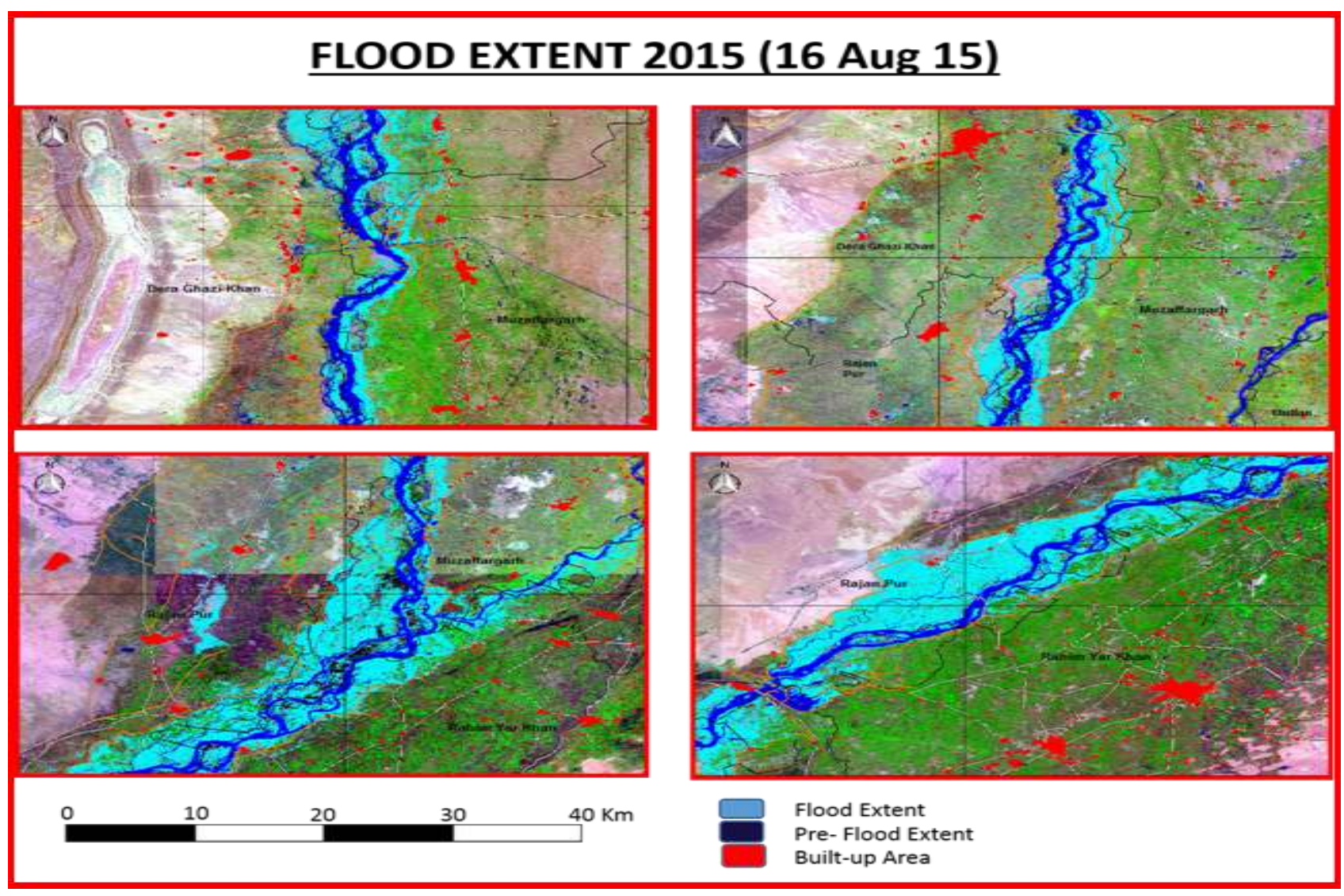

Figure 7: Flood Extent and Damages (16 $6^{\text {th }}$ Aug 2015).

Table 2: Damage Assessment (NDMA Report Pakistan, 2015)

Fields of Damages in Study Area

\begin{tabular}{lcccccccc}
\hline District & $\begin{array}{c}\text { Inundated } \\
\text { Area } \mathbf{K m}^{2}\end{array}$ & Villages & $\begin{array}{c}\text { Rail } \\
\mathbf{K m}\end{array}$ & $\begin{array}{c}\text { Road } \\
\mathbf{K m}\end{array}$ & $\begin{array}{c}\text { Agriculture } \\
\text { (Acre) }\end{array}$ & $\begin{array}{c}\text { BU } \\
\text { Area }\end{array}$ & $\begin{array}{c}\text { People } \\
\text { Displaced }\end{array}$ & $\begin{array}{c}\text { Live } \\
\text { Stock }\end{array}$ \\
\hline DG Khan & 527 & 78 & 00 & 29.51 & 286554 & 36 & 30000 & 2800 \\
Muzaffargarh & 821 & 197 & 00 & 12 & 104 & 134 & 1000 & 1800 \\
Rahim Yar Khan & 500 & 108 & 00 & 11.25 & 165 & 38 & 1800 & 2500 \\
Rajan Pur & 1038 & 213 & 37 & 160 & 200.44 & 93 & 32000 & 16 \\
Multan & 25 & 2 & 00 & 10 & 50 & 10 & 100 & 20 \\
\hline
\end{tabular}


Table 3: Classification Table for Accuracy Assessment.

\begin{tabular}{llcccc}
\hline Classes & Water & Vegetation & $\begin{array}{c}\text { Classification Fields } \\
\text { Area }\end{array}$ & Pasture & $\begin{array}{c}\text { Row Total (Ground } \\
\text { Truth) }\end{array}$ \\
\cline { 2 - 6 } Water & 40 & 0 & 0 & 10 & 50 \\
Vegetation & 0 & 40 & 23 & 0 & 63 \\
$\begin{array}{l}\text { Built-up } \\
\text { Area }\end{array}$ & 0 & 0 & 17 & 0 & 30 \\
$\begin{array}{l}\text { Pastures } \\
\text { Total Column }\end{array}$ & 0 & 0 & 0 & 30 & 17 \\
Overall Acuracy & 40 & 40 & 40 & 40 & \\
Kappa Coieficent & $79.3 \%$ & & & & \\
\hline
\end{tabular}

\subsection{Accuracy Assessment}

As per values of table 3, accuracy assessment was calculated by the sample size of object-based classification and ear-marked number of classes was water, vegetation class, pastures and built-up areas. Accuracy in water class was 40/40*100 $=100 \%$, vegetation class was also $100 \%$, built-up area had $42.5 \%$ and pastures were $75 \%$ accurately classified. Omission error for water and vegetation was $0 \%$, pastures had $25 \%$ and built-up are assessed with $57.5 \%$. Commission errors are $20 \%$ for water, $36.5 \%$ for vegetation; no commission error was there for built-up areas and pastures. Overall accuracy of this classification was resulted as $79.3 \%$. Kappa coefficient is a measure that evaluates any classification accuracy validation. When $\mathrm{K}_{\text {hat }}$ is ranging the values with $>0.80$; it is considered as strong accuracy, from 0.40 to 0.80 very good accuracy and when coefficient is $<0.40$ then it is believed poor accuracy (Stehman, 1996). The value of classification for kappa coefficient was 0.72 , which was representing very good accuracy.

\section{Conclusion}

Natural disasters like flash floods are very common everywhere in the world which cannot be stopped in any case however one can do good planning to minimize the vulnerability to take solid steps by opting mitigation measures. Basing upon the derived results as shown in the study area (Southern Punjab), it is concluded that remote sensing and GIS techniques provide an efficient analysis in the flood monitoring assessment with requisite results in the form of visual statistical analysis which help an organization as well as responsible government and non-government officials for efficient decision-making in terms of relief, rehabilitation, quick response, rebuilt the damaged infrastructure and future mitigation. Object-based classification and GIS methods were proved an excellent option for construction of flood extents. These extents were derived before, during and post flood dates from $16^{\text {th }} \mathrm{Jul} 2015$ to $16^{\text {th }}$ Aug 2015 . Th above-mentioned method of classification was developed by using various techniques of e-cognition, basing on NDVI, MNDWI and NDBI. The current paper supports the fact that different imageries taken from satellites namely MODIS, Sentinel-1 and Landsat 8 , can be useful for the end users for decision-making in quick response during and after flood emergencies. This study is a proof of good tools if a comprehensive mapping is carried out by the use of remote sensing and GIS techniques. It can help the disaster management personnel to be more prepared for any future flood crisis along with other related risks.

\section{Acknowledgment}

The Authors are very indebted to USGS, NDMA and SUPARCO for their cooperation in providing data and helping to establish maps on the subject.

\section{References}

Ahuchaogu, E. U., Baywood, C., Gift, U., and Ojinnaka, O. (2015). Flood Hazard Analysis And Damage Assessment Of 2012 Flood In Anambra State Using GIS and Remote Sensing Approach. International Journal of Environmental Studies, 201(15), 17-21. 
Ahmed, B., Wei, S., Fu, Y. G., Shabbir, M., Nabi, G., and Khan, K. U. (2014). Effects of Floods policy in Pakistan and Management Issues: ( Case of District Dera-Ghazi Khan ). International Journal of Advanced Research, 2(10), 967-974.

Belal, A. A. (2011). Detecting urban growth using remote sensing and GIS techniques in Al Gharbiya governorate , Egypt. The Egyptian Journal of Remote Sensing and Space Sciences, 14(2), 73-79.

Bhuiyan, S. R., and Baky, A. Al. (2014). Digital elevation based flood hazard and vulnerability study at various return periods in Sirajganj Sadar Upazila, Bangladesh. International Journal of Disaster Risk Reduction, 10, 48-58.

CWSA Peace Resiliance. (2015). 2015 Monsoon Contingency Plan for Pakistan - Report. Community World Service Asia, 1-28.

FFD., and Miinistry of Water \& Power Pakistan. (2015). Annual Flood Report 2015. AFR 2015, 15(1), 1-97.

Guo, E., Zhang, J., Ren, X., Zhang, Q., and Sun, Z. (2014). Integrated risk assessment of flood disaster based on improved set pair analysis and the variable fuzzy set theory in central Liaoning Province, China. Natural Hazards, 74(2), 947-965.

Hazarika, N., Das, A. K., and Borah, S. B. (2015). Assessing land-use changes driven by river dynamics in chronically flood affected Upper Brahmaputra plains, India, using RS-GIS techniques. The Egyptian Journal of Remote Sensing and Space Science, 18(1), 107-118.

Iqbal, I., Iqbal, Z., and Ravan, S. (2015). Lessons Learnt from Floods in Pakistan. SUPARCO Pakistan, 1(1), 1-33.

Isa, Q. A. (2015). Disaster Management Strategy 2015. Pakistan Poverty Alleviation Fund, 7(2), 1-76.

Kalantari, Z., Nickman, A., Lyon, S. W., Olofsson, B., and Folkeson, L. (2014). A method for mapping flood hazard along roads. Journal of Environmental Management, 133, 69-77.

Kirsch, T. D., Wadhwani, C., Sauer, L., Doocy, S., and Catlett, C. (2012). Impact of the 2010 Pakistan Floods on Rural and Urban Populations at Six Months. PLoS Currents, 4, 1-7.

Memon, A. A., Muhammad, S., Rahman, S., and Haq, M. (2015). Flood monitoring and damage assessment using water indices: A case study of Pakistan flood-2012. The Egyptian Journal of Remote Sensing and Space Science, 18(1), 99-106.

Memon, N. (2015). Climate Change and Natural Disasters in Pakistan. SPO National Centre Islamabad, Pakistan, 2(36), 1-65.

NDMA Report Pakistan. (2015). Flash Floods in Pakistan 2015, Rapid Assessment Report. FFD (Vol. August).

PMD and Flood Forcasting Division. (2015). Government of Pakistan, National Disaster Management Authority Monsoon Weather Situation Report 2015.

Shah, S. J. H. (2020). Role of Institutions in Combating the Effects of Flood Hazard in Punjab- A Case Study of District Chiniot. Arts and Social Sciences, 1(1), 33-43.

Shakeel, M., Munir, K., Hina, K., Saeed, R., Arshad, Q., Noreen, M., and Ahmed, T. (2015). Application of Remote Sensing and Gis Technology for Pre and Post Flood Analysis ( 2014 ) along River Chenab, Pakistan. Earth Science \& Climate Change, 6(10), 6-10.

Shakoor, A. (2015). Situation Analysis Report, Flash Floods 2015 in Pakistan. Alkhidmat Foundation Pakistan, 1(1), 1-25.

Sowmya, K., John, C. M., and Shrivasthava, N. K. (2015). Urban flood vulnerability zoning of Cochin City, southwest coast of India, using remote sensing and GIS. Natural Hazards, 75(2), 1271-1286.

Stehman, S. V. (1996). Estimating the Kappa Coefficient and its Variance under Stratified Random Sampling. Photogrammetric Engineering \& Remote Sensing, 62(4), 401-407.

Tamta, K., and Bhadauria, H. S. (2015). Object-Oriented Approach of Landsat Imagery for Flood Mapping. International Journal of Computer Application, 122(16), 6-9.

Zhang, X. Y., Cai, C., and Li, P. J. (2014). Regional urban area extraction using DMSP-OLS data and MODIS data. IOP Conference Series: Earth and Environmental Science, 17(1), 012156. 